\title{
Historical controversies about the thalamus: from etymology to function
}

\author{
Carlo Serra, MD, ${ }^{1}$ Lelio Guida, MD, ${ }^{1,2}$ Victor E. Staartjes, BMed, ${ }^{1}$ Niklaus Krayenbühl, MD, ${ }^{1}$ and \\ Uğur Türe, MD ${ }^{3}$
}

\begin{abstract}
1Department of Neurosurgery, Clinical Neuroscience Centre, University Hospital Zürich, University of Zürich, Switzerland; ${ }^{2}$ Department of Neurosurgery, Monza, University of Milan, Italy; and ${ }^{3}$ Department of Neurosurgery, Yeditepe University School of Medicine, Istanbul, Turkey
\end{abstract}

\begin{abstract}
The authors report on and discuss the historical evolution of the 3 intellectual and scientific domains essential for the current understanding of the function of the human thalamus: 1) the identification of the thalamus as a distinct anatomical and functional entity, 2) the subdivision of thalamic gray matter into functionally homogeneous units (the thalamic nuclei) and relative disputes about nuclei nomenclature, and 3) experimental physiology and its limitations.
\end{abstract}

Galen was allegedly the first to identify the thalamus. The etymology of the term remains unknown although it is hypothesized that Galen may have wanted to recall the thalamus of Odysseus. Burdach was the first to clearly and systematically define the thalamus and its macroscopic anatomy, which paved the way to understanding its internal microarchitecture. This structure in turn was studied in both nonhuman primates (Friedemann) and humans (Vogt and Vogt), leading to several discrepancies in the findings because of interspecies differences. As a consequence, two main nomenclatures developed, generating sometimes inconsistent (or nonreproducible) anatomo-functional correlations. Recently, considerable effort has been aimed at producing a unified nomenclature, based mainly on functional data, which is indispensable for future developments. The development of knowledge about macro- and microscopic anatomy has allowed a shift from the first galenic speculations about thalamic function (the "thalamus opticorum nervorum") to more detailed insights into the sensory and motor function of the thalamus in the 19th and 20th centuries. This progress is mostly the result of lesion and tracing studies. Direct evidence of the in vivo function of the human thalamus, however, originates from awake stereotactic procedures only.

Our current knowledge about the function of the human thalamus is the result of a long process that occurred over several centuries and has been inextricably intermingled with the increasing accumulation of data about thalamic macroand microscopic anatomy. Although the thalamic anatomy can currently be considered well understood, further studies are still needed to gain a deeper insight into the function of the human thalamus in vivo.

https://thejns.org/doi/abs/10.3171/2019.6.FOCUS19331

KEYWORDS thalamus; neuroanatomy; history

$\mathrm{I}$ $\mathrm{N}$ the 23rd book of the Odyssey, after having repossessed his home by killing the suitors, Odysseus finally reveals himself to Penelope who, doubtful, does not engage him and asks her nurse to move the giant bed out of her room and make it up for "the stranger" to sleep in. Then Odysseus, "in a burst of anger" replies: "[...] of men there is no mortal that lives, be he never so young and strong, who could easily pry it from its place, for a great token is wrought in the fashioned bed, and it was I that built it and none other" (translation from perseus.uchicago.edu). Odysseus reveals that he carved the bed out of a giant olive tree placed in the center of the court and he built the room around it. In hearing these secret details, Penelope finally recognizes the stranger as her beloved husband.

These sublime verses by Homer, dating from almost 3000 years ago, provide a notable, artistic, translated image of the main features of the thalamus. The bridal cham-

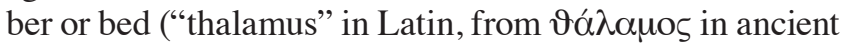
Greek) that Odysseus built is unmovable and solidly placed in the most intimate and inner place of the house, sitting upon the trunk (the brainstem) of an olive tree, and densely connected through its branches (the thalamic peduncles) to its foliage (the telencephalon). However, we do not know if Galen, the personal physician of the emperor Marcus Au- 
relius, was thinking of Homer when he reportedly, for the first time, used the term "thalamus of the ventricles," nor it is clear what he really meant by that term.

The accumulation of knowledge about the function of the thalamus proceeded parallel to the cultural "Zeitgeist" of the corresponding historic periods, and to the development of technical means for anatomical and functional investigation, which eventually determined the scope of the "explorable" and the focus of interest. The ancient anatomists could concentrate on gross anatomy only, having trouble even seeing the thalamus itself, whereas authors of the 20th century could have a lively debate about the cytoarchitectonic functional subdivision of the nuclear mass of the thalamus.

The chronology of the discoveries and studies of the thalamus is impressive. ${ }^{5,24,52}$ The aim of this historical review is to focus on 3 controversial aspects that have been vigorously disputed over the centuries and which were crucial in the development of our current understanding of thalamic function: 1) the identification of the thalamus as a distinct anatomical and functional entity, together with the first speculations on its function, which occurred more than 1000 years after Galen, and represented the indispensable prerequisite for successive speculations and discoveries about its function; 2) the subdivision of thalamic gray matter into functionally homogeneous units (the thalamic nuclei); and 3) the achievement and refining of the contemporary knowledge of the function of the thalamus.

\section{The Identification of the Thalamus: "Thalamus Nervorum Opticorum" Versus the Thalamus of Odysseus}

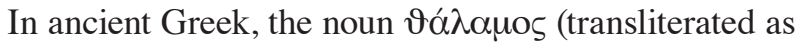
"thalamus") was used to indicate the innermost chamber of Greek mansions. It is accepted that Galen was the first to use this term in a medical context in the "De Usu partium." The original text of Galen further specified that the thalamus served the optic nerves-i.e., "[...] propter illos nervos factus est [...]"; hence the definition "thalamus nervorum opticorum," which dominated the classic literature thereafter. ${ }^{50,73}$ It is not clear, however, why Galen chose this term and what anatomical structure he wanted to describe with this word. According to Walker ${ }^{71}$ Galen's intention was probably to link nomenclature with function, in that he identified the thalamus as a sort of chamber, or anteroom, for the optic nerves. Jone ${ }^{24}$ believed that Galen was thinking of the thalamus as a sort of storeroom for the vital spirit (the pneuma). In 1822, Burdach ${ }^{5}$ vehemently stated that Galen did not see the thalamus at all, since he could not have given the name "chamber" to a solid mass like that of the thalamus. However, the choice of Burdach to give the name "pulvinar" (Latin for "pillow") to the most posterior part of the thalamus is at least ironic; in classic Greco-Roman literature, the term "thalamus" means also, if not mostly, "room for the bridal couple" or even "bridal bed."

The parallel with the Odyssey is thus intriguing: as a literate of the classic world, Galen was certainly aware of the poems of Homer. Moreover, it is known that Galen refined his anatomical knowledge in Alexandria, Egypt,

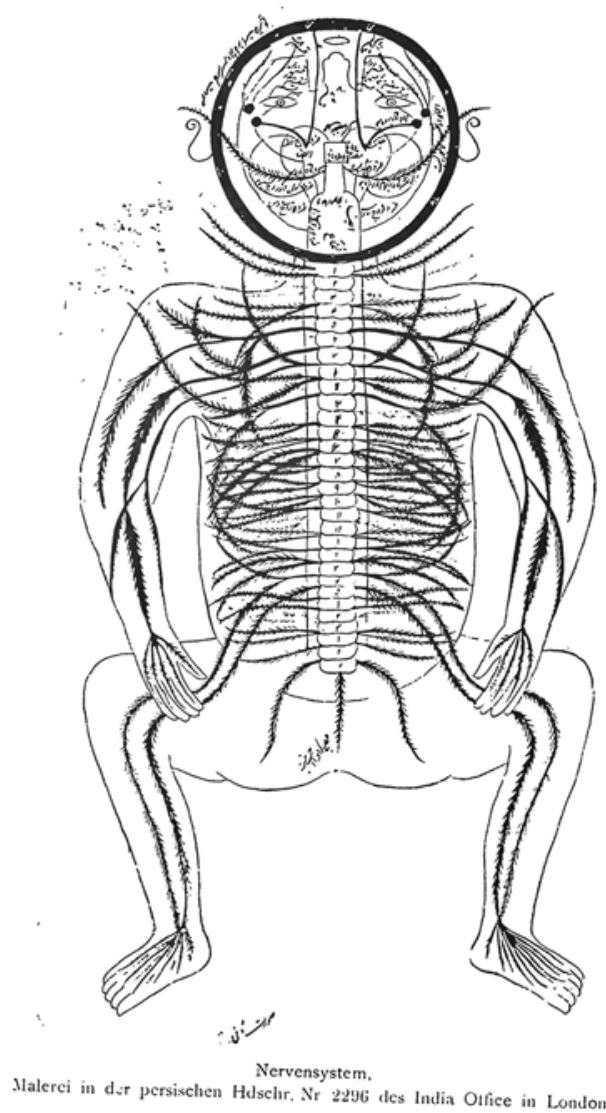

FIG. 1. Depiction of the nervous system in the Tashri-i-mansuri, an anatomical text written by the Persian physician Mansur ibn Muhammad ibn Ahmad ibn Yusuf ibn llyas (AD 1380-1422). The specimen lies on the abdomen and the head is reflected backward (the chin is represented at the highest point of the picture). The brain is viewed from a posterosuperior position so that the whole of the central nervous system, brain, and spinal cord (including the emergence of the rootlets from the spinal canal) can be seen in a single picture. The small square in the middle of the head represents the center of the head. Four circles are represented: two smaller, closer to the square, and two slightly bigger. The text near the small circles reads, "Single nerve of the 1st pair. Likewise. Single nerve and 3rd pair," whereas that near the bigger circles reads, "Single nerve of the 3rd pair, single nerve of the 6th pair." The meaning of the text remains unclear; however, according to Sudhoff, these pictures would be the result of the influence of the ancient Alexandrine tradition, through Byzantine into Islamic medicine. From Sudhoff K. Ein Beitrag zur Geschichte der Anatomie im Mittelalter, speziell der anatomischen Graphik nach Handschriften des 9. bis 15. Jahrhundert. Leipzig: Barth, 1908. Public domain.

where Herophilos of Chalcedon had already, in the 4th century $\mathrm{BC}$, identified and named the choroid plexus and the body of the fornix. Although no written evidence is available, it is thus likely that Herophilos and his later followers also saw the thalamus. In fact, in a schematic depiction of the central nervous system of the Tashri-imansuri (Fig. 1), which, according to Sudhoff, ${ }^{62}$ emulates lost drawings of the Alexandrine school, two ovoids are shown sitting unequivocally on top of the brainstem, much as the $\vartheta \alpha ́ \lambda a \mu o s$ of Odysseus sits atop the trunk of the olive tree. Those round structures, according to an interesting suggestion of Gailloud and colleagues ${ }^{16}$ could 




FIG. 2. Images from Anatomici summi septemdecim tabulae quas nunc primum edit atque explicat iisque alias addit de structura mammarum et de tunica testis vaginalis (Parma, 1775, public domain) depicting the thalamus three-dimensionally (Fig. I and Fig. II) and in standard coronal view (Fig. III). The geniculate bodies are mentioned (and localized) for the first time in anatomical literature (Fig I, D). Likewise, for the first time it is clearly stated that the phrase "thalamus opticorum nervorum" is no longer adequate (Fig II, B: "Thalami nervorum opticorum, sic inepte appellati").

possibly represent a first, albeit sketchy, depiction of the thalamus. Lastly, if as Walker ${ }^{71}$ said, the word "thalamus" was chosen just to mean "anteroom or chamber" of the optic nerves, then it appears at least odd that it has been used only in this context. Space-connoting terms (such as atrium, ventricle, recess, cavum, etc.) tend to recur often in classical anatomical nomenclature, whereas eponyms only are unique (torcular, pons, calamus scriptorius, etc.).

As appealing as the Odyssey theory may be, it will never be known what Galen saw and what he meant with his choice. For this reason, it is Mundino da Liuzzi ${ }^{41}$ who must be credited as the first to unequivocally see and describe the thalamus, although he did not offer any hypothesis about its function. What Mundino describes, together with several other later authors, is the ventricular surface of the thalamus, which received over the centuries several different names (anche, monticulus, nates, testes). It was Riolan, ${ }^{50}$ in 1610 , who revitalized the phrase "thalamus nervorum opticorum" (Latin for "thalamus of the optic nerves"), which prevailed and persisted for a long time in the anatomical literature ("Seehügel" in German and "couche optique" in French literature) notwithstanding the fact that Santorini ${ }^{53}$ subsequently traced the optic nerve back to the lateral geniculate body (which Santorini himself named) and thus suggested for the first time that the definition "thalami nervorum opticorum" was no longer adequate (Fig. 2).

The 1822 publication of the seminal work of Burdach, Vom Baue und Leben des Gehirns, ${ }^{5}$ represents the turning point in the understanding of macro- as well as microscopic thalamic anatomy. Burdach not only used the term "pulvinar" for the first time (Fig. 3), but also did a very precise, quantitative, and systematic report on the limits and dimensions of the thalamus and of its anatomical relationships, providing the framework on which anatomists of the 19th and 20th centuries would work. Among these, at least the names of Arnold, ${ }^{1}$ Monro, ${ }^{39}$ Mayo, ${ }^{36}$ Meynert, ${ }^{37}$ Luys, ${ }^{28,29}{ }^{2}$ Foville, ${ }^{13}$ Dejerine, ${ }^{7}$ and Schlesinger ${ }^{55}$ deserve to be mentioned (Fig. 4). Moreover, on alcohol-hardened brain cuts, Burdach described the internal microarchitecture of the thalamus; he identified the lamina medullaris interna and externa (i.e., the anatomical boundaries of the thalamus) and, based on these boundaries, could subdivide the nuclear mass of the thalamus into superior, internal, and external portions, paving the way to understanding the thalamic structure, connections, and function.

\section{The Thalamic Nuclei: Architectonic Versus Functional Subdivision}

As mentioned above, in 1822, Burdach ${ }^{5}$ became the first to identify the lamina medullaris interna and thus to subdivide the thalamic nuclear mass into superior, internal, and external (nucleus cinereus internus, externus, and superior) portions based on their position relative to the lamina medullaris interna (i.e., based on topographic criteria). Similarly, 40 years later, Luys ${ }^{28,29}$ identified the center anterieur, center moyen, center median, and center posterior portions (Fig. 5), and Forel, ${ }^{11}$ in 1877, applied the nomenclature (anterior, posterior, ventral, and lateral) that served as the base for subsequent generations of scientists. At the turn of the 19th century, the scope of microscopic anatomy was further enlarged as a result of significant advancements in histological techniques (Nissl staining, ${ }^{43,44}$ myelin staining, ${ }^{72}$ Golgi staining, ${ }^{18}$ the Marchi technique $^{34}$ ), which led to several further studies of the finer 


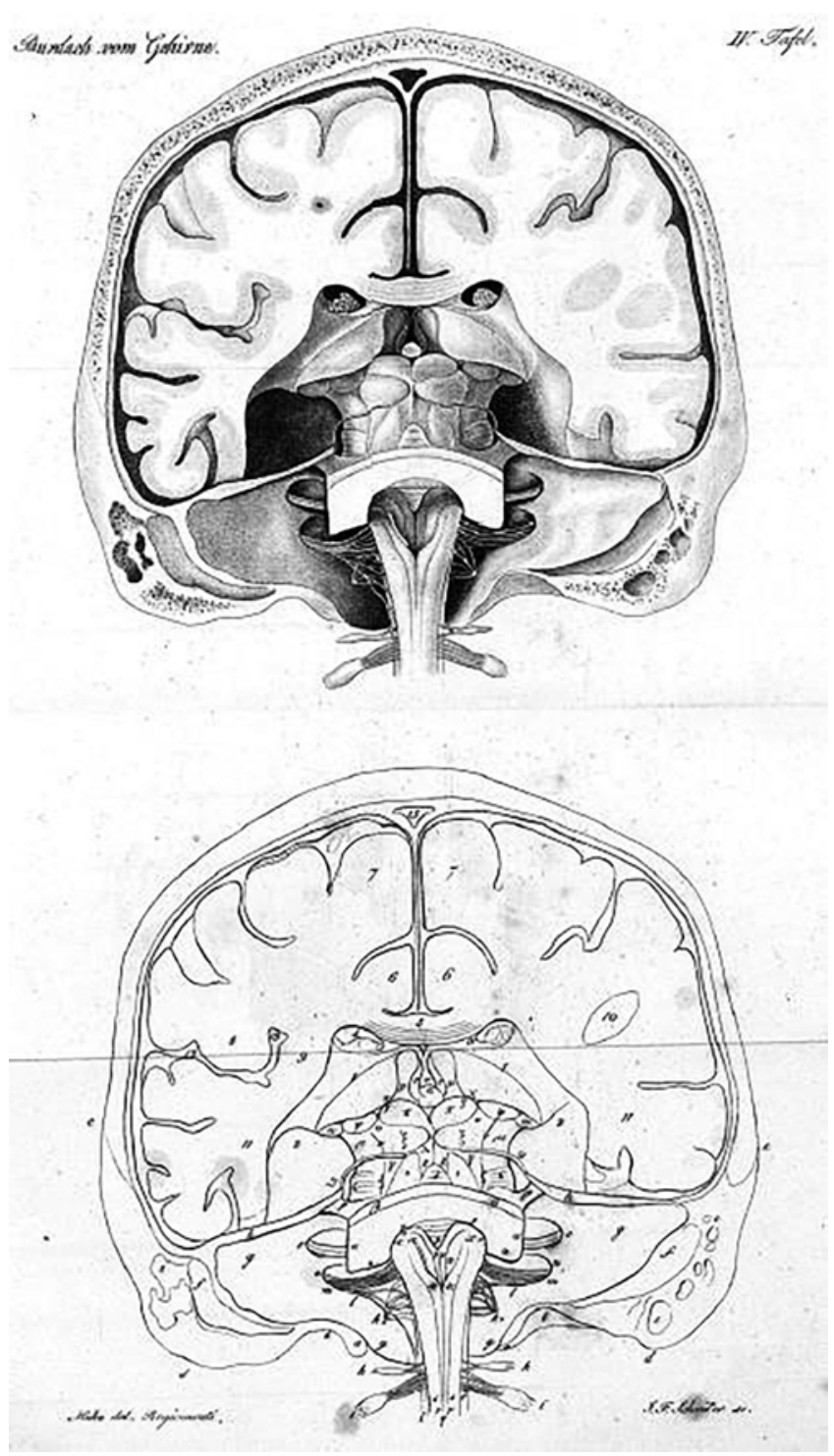

FIG. 3. Image from Burdach KF: Vom Baue und Leben des Gehirns (Leipzig, 1822, public domain). The illustration is the first in anatomical literature mentioning the pulvinar (as "Polster" in German, labeled here with X).

cytoarchitecture of the thalamus. ${ }^{7,23,66}$ At the same time, however, pioneering ablative studies (based on retrograde degeneration of thalamic nuclei after ablation of a select cortical area) and lesional studies ${ }^{66,67}$ started showing the first elements of connectivity, and thus of function of the thalamus. The evidence that only specific parts of the thalamus degenerate following damage of functionally related cortical areas was so remarkable that some authors, such as Meynert in 1872, ${ }^{65,66}$ started suggesting that thalamic cells should be grouped (and named) in nuclei only as long as they show corresponding connections. In other words, microscopic topographic subdivision of the thalamus was to be determined based on functional criteria only.

However, this approach was not unanimously accepted, and the subdivision and nomenclature of the thalamic nu- clei remained a matter of intense discussions for several decades (Fig. 6). ${ }^{20,22,46,48,54}$ Essentially, ${ }^{24,58}$ two large families of nomenclature are recognized: 1) the one initially adopted for experimental animals, which dates back to Friedemann ${ }^{14}$ and was later revised by Hirai and Jones ${ }^{20}$ and then transposed to humans, and 2) the one currently still used in the neurosurgical community for stereotactic surgery, which was first established by Vogt and Vogt ${ }^{69}$ and later popularized by Hassler in his Schaltenbrand stereotactic atlas, ${ }^{54}$ based on postmortem human brain specimens.

The differences between the two nomenclatures are due to several factors, the most important probably being that the human thalamus is bigger than that of nonhuman primates. Nuclear borders are thus much clearer, hence the ease in delimiting them and possibly in finding subdivisions which in the monkey are not so readily identifiable (this applies particularly to the pulvinar and to the ventral and lateral thalamic region). For this reason, some of these subdivisions where brought together by Hirai and Jones, unless they could be justified not only through the cytoarchitecture but also by different patterns of fiber connections. As highlighted by Macchi and Jones in a nice review on this topic, ${ }^{30}$ areas with different cytoarchitectonic patterns but the same functional connections are to be understood as a single nucleus and should thus be correspondingly named. This concept was further extended by Percheron and colleagues, ${ }^{48}$ who proposed a totally new subdivision of the so-called motor thalamus based on its afferences (pallidal, cerebellar, lemniscal) only, thereby revitalizing the old concept of Meynert. ${ }^{60,61}$

It is thus clear from these considerations that the parceling of the thalamus needs to take both cytoarchitecture and connectivity (i.e., function) into account. Based on these elements, Morel and associates ${ }^{40}$ translated the concepts of Hirai and Jones into an atlas of the thalamus and basal ganglia based on human specimens. They identified the borders of the thalamic nuclei based on multiarchitectonic criteria, including Nissl staining and myelin staining, but also based on immunocytochemical identification of the calcium-binding proteins, which have been shown to segregate partly according to functional criteria in humans. ${ }^{6}$ The resulting nomenclature is now the one accepted by the International Federation of Associations of Anatomists (IFAA) and introduced as standard in the Terminologia Neuroanatomica. ${ }^{63}$ It represents furthermore a brilliant example of a rare instance where functional localization became a crucial factor for a precise anatomical definition.

\section{From the "Thalamus Opticorum Nervorum" to the Contemporary Era}

As previously noted, initial insights into thalamic function were based on anatomical inferences and thus postulated a role for the thalamus mostly in the visual pathways-hence the name "thalamus opticorum nervorum." The observations of Santorini about the true course of the optic nerve could not significantly change the dominant view in the scientific community. But with the first experimental ablative studies of the first half of the 19th century, 



FIG. 4. Overview of some of the most famous anatomical illustrations of the thalamus and of its macroscopic anatomy and connections. a: Illustration from Alexander Monro, Observations on the Structure and Functions of the Nervous System, Illustrated with Tables (The London Medical Journal 4:113-135, 1783, public domain), showing a detailed image of the lateral ventricle's surface $(C)$ and a description of the foramen of Monro. b: Illustration from Friedrich Arnold, Tabulae anatomicae: quas ad naturam accurate descriptas in lucem edidit (Band 1): Icones cerebri et medullae spinalis: decem tabulae elaboratae et totidem adumbratae (Zurich, 1838, public domain). The posterior surface of the thalamus is depicted along with the posterior thalamic radiation contributing to the corona radiata. c: Drawing from Achille Louise Foville, Traité complet de l'anatomie, de la physiologie et de la pathologie du système nerveux cérébro-spinal (Paris, 1844, public domain) showing the detailed iconography of the gross morphology of the thalamus, the diencephalic structures, and the thalamic white matter tracts including the ansa peduncularis and its subcomponents. d: Sectional anatomy with thalamic radiations illustrated and named from Jules Dejerine, Anatomie des centres nerveux par J. Dejerine Avec la collaboration de Madame Dejèrine-Klumpke (Paris, 1895, public domain). e-g: Three illustrations showing the evolution of the depiction of thalamic peduncles over the 19th and 20th centuries. Panel e: From Jules Bernard Luys, Recherches sur le système nerveux cérébro-spinal: sa structure, ses fonctions et ses maladies (Paris, 1865, public domain). Panel f: Reprinted from Theodore Meynert, Psychiatrie. Klinik der Erkrankungen des Vorderhirns begründet auf dessen Bau, Leistungen und Ernährung (Wien, 1884, public domain). Panel g: Three-dimensional depiction illustrating the main thalamic nuclei and their spatial relationships. Reprinted by permission from Springer Nature Customer Service Centre GmbH: Springer Nature, The Upper Brainstem in the Human: Its Nuclear Configuration and Vascular Supply by Benno Schlesinger. Copyright 1976. https:// link.springer.com/book/10.1007/978-3-642-66255-3. h: Drawing showing the relationship of the thalamus with the surrounding structure. The images are based on a wax model done by Josef Klingler. Reprinted by permission from Springer Nature Customer Service Centre GmbH: Springer Nature, Zeitschrift für Anatomie und Entwicklungsgeschichte, Ein zerlegbares Modell der Vorderund Mittelhirnkerne des Menschen mit Einschluß der angrenzenden Rindenpartien, Josef Klingler. Copyright 1942.

it became apparent that the function of the thalamus was much more complex.

\section{The Introduction of Ablative Techniques}

The introduction of ablative techniques represented a turning point in the understanding of thalamic function. A key figure in the early phases of ablative studies was Bartolomeo Panizza (1785-1867), who in 1855 published an essay about the visual pathway ("Osservazioni sul nervo ottico" $\left.{ }^{97}\right)$. He conducted the first "prospective" ablative experiments, inducing a lesion in the visual pathway in newborn animals (for instance, cornea removal in rabbits, ocular bulb enucleation in dogs) and examining the asymmetry and atrophy of the structures involved in postmortem examinations (Fig. 7) after a variable interval (usually 1 year). Among the other structures examined, he almost always found atrophy of the contralateral thalamus and compensatory hypertrophy of the ipsilateral one. This pio- 


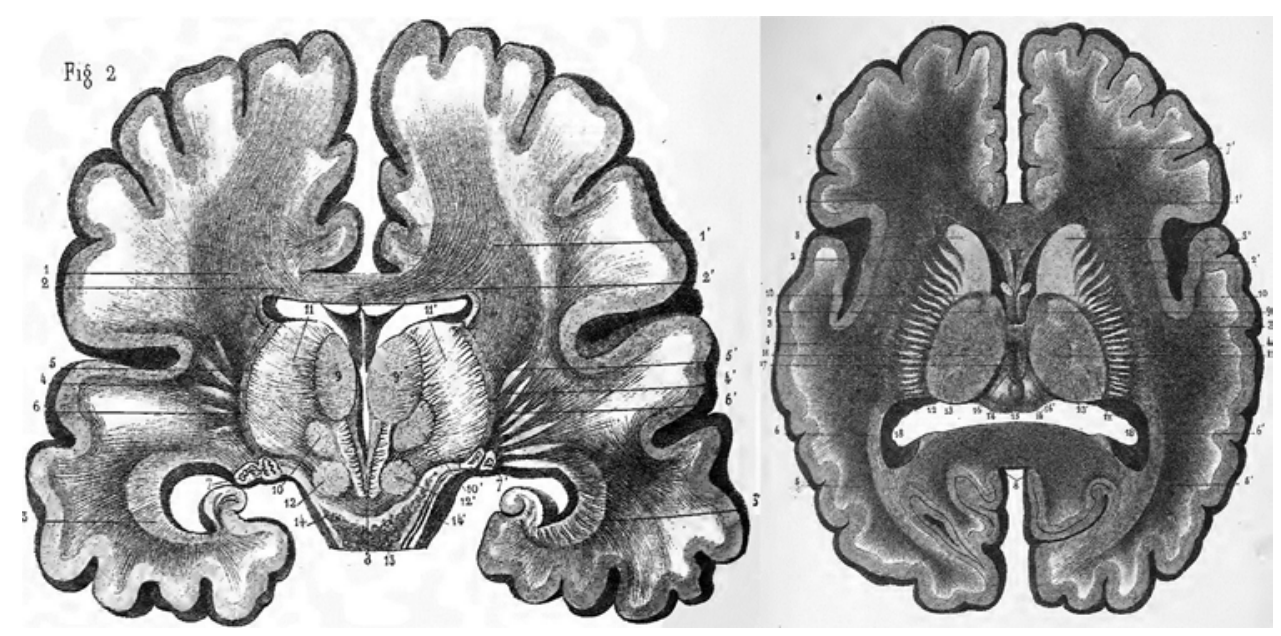

FIG. 5. Left: Coronal section of a human brain showing the nuclear differentiation of the couches optiques into centers medians $\left(10,1^{\prime}\right)$, centers moyennes $\left(9,9^{\prime}\right)$, and corps genouillés $\left(7,7^{\prime}\right)$. This picture also documents fibers projecting from both thalami ("Fibres convergentes supérieures de la region moyenne allant se perdre sur la face convexe de la couche optique, fisceaux conoides," 1, 1', 2, 2', 4, 4', 6, 6'). Right: Axial section showing the centers anterieurs (10, 10'), centers moyennes (11, 11'), and centers posterieurs $\left(13,13^{\prime}\right)$ together with the so-called converging fibers penetrating the thalamus $\left(12,12^{\prime}\right)$. From Jules Bernard Luys, Recherches sur le système nerveux cérébro-spinal: sa structure, ses fonctions et ses maladies (Paris, 1865, public domain).

neering method was subsequently enriched by von Gudden and his collaborators in their famous work on retrograde degeneration ${ }^{65}$ (see below). In 1809, Luigi Rolando was one of the first authors to document the effects of experimental lesions of the "thalamus opticorum." ${ }^{51}$ Reports describing its destruction revealed a wide variety of effects according to the species examined: motor incoordination in mammals (sheep, pigs, dogs, hamsters, lambs), blindness and stupor in birds (chickens, ravens, ducks), and a decline in cognitive function in reptiles (turtles). Around the same time, François Magendie ${ }^{31}$ also performed experiments of in vivo thalamic ablation in frogs and birds, documenting various degrees of motor impairment and suggesting that the "couche optique" was involved not only in visual but also in motor function, a thesis strongly supported later by Vulpian. ${ }^{70}$ The vast scope of this catalog of possible functions of the thalamus was basically due to the coarseness of the initial ablative techniques, which often included also portions of brain parenchyma adjacent to the thalamus. These initial experiences were deemed distasteful and imprecise and were thus harshly criticized by, among others, Marie Jean Pierre Flourens (1794-1867), who introduced a systematic methodology ("méthode isolatrice") for ablative experiments based on the exact recognition of the anatomical structure injured and on the reproducibility of the results (each lesion had to produce the same clinical effect). ${ }^{10}$ The conceptual methodological improvement suggested by Flourens, together with the increasing precision of lesioning techniques, ${ }^{8,12,45}$ were crucial steps in the further understanding of thalamic function.

\section{The Role of the Thalamus in Sensory Function}

Edward Fourniér ${ }^{2}$ was one of the first to suspect a role of the thalamus in transmitting sensory function. He injected zinc chloride colored with aniline blue into the thalamus of dogs, documenting almost constant loss of sensibility.
In some instances, he also registered some motor impairment ("mouvements de galop"), an effect he explained as the result of the chloride-induced diffusion toward the neighboring corpus striatum neurons. Veyssière in 1874 (dogs), Ferrier in $1876^{8}$ (monkeys), and Nothnagel in $1873^{45}$ (monkeys) partly confirmed these findings. Indeed, as noticed by Roussy in a historical introduction to his work on the function of the thalamus, ${ }^{52}$ lesional studies with injection of cytotoxic drugs still were not specific enough, since the injected drug could spread to structures other than those targeted. The introduction of electrical stimulation of neural structures by Fritsch and Hitzig ${ }^{15}$ revolutionized the field, allowing much more accurate lesion placement, and led Ferrier ${ }^{8}$ to suggest a model of the sensory pathway parallel to that of the motor pathway ("The optic thalamus bears the same relation to the tegmentum, or sensory tracts of the crus cerebri, which the corpus striatum has to the foot or motor tracts").

This evidence obtained in experimental animals was then convincingly supported by anatomo-clinical data, particularly those of Dejerine, ${ }^{7}$ who reported the results of several autopsies of stroke patients with thalamic lesions who had developed hemi-anesthesia, thereby clearly and conclusively assigning the thalamus a role in sensory function.

\section{Functional Connections of the Thalamus}

At the turn of the 19th century, thalamic function was thus investigated mainly through experiments with retrograde degeneration, which consolidated its involvement in the somatosensory pathway. For instance, the experimental ablation of cortical areas in newborn rabbits and the subsequent analysis of the degenerated corresponding thalamic nuclei stained with Nissl dye led von Gudden, ${ }^{65}$ and later his assistants von Monakow ${ }^{66}$ and Nissl, ${ }^{44}$ to identify in mammals (especially rabbits) several thalamo-cortical 
Feremutsch / Simma

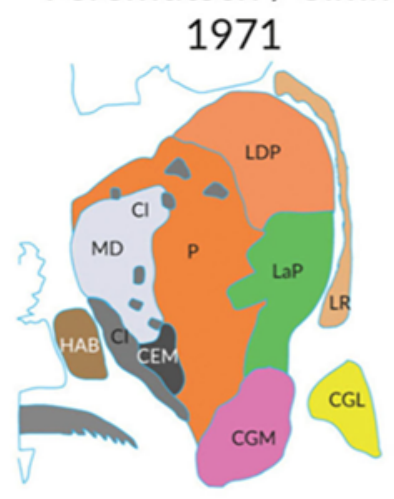

Hirai and Jones 1989

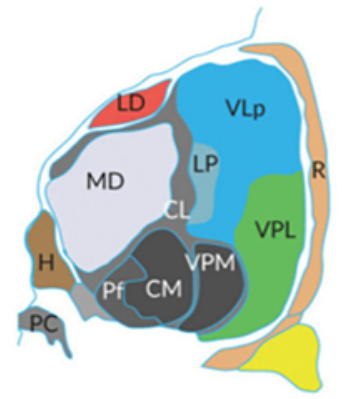

Ilinsky et al. 2018

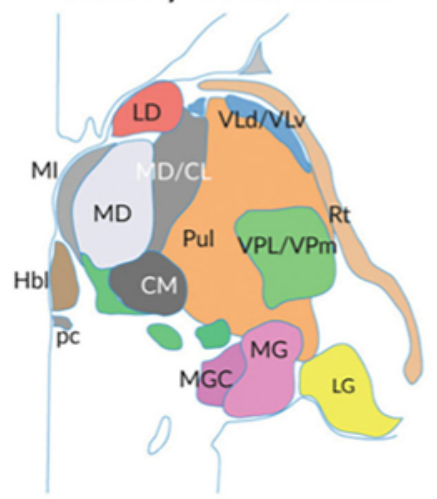

Hopf et al. 1971

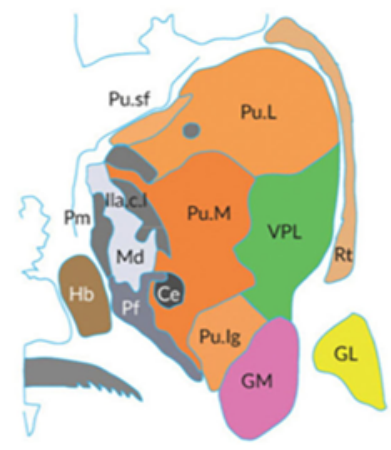

Morel et al. 1997

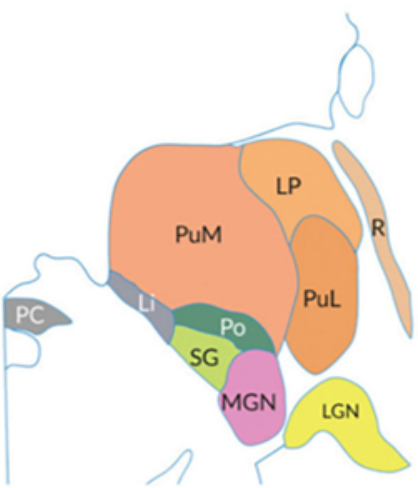

Ding et al. 2016

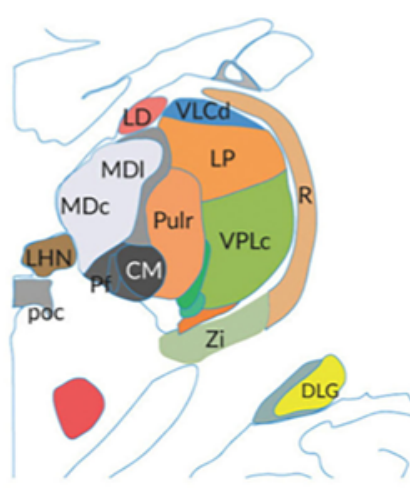

van Buren / Borke 1972

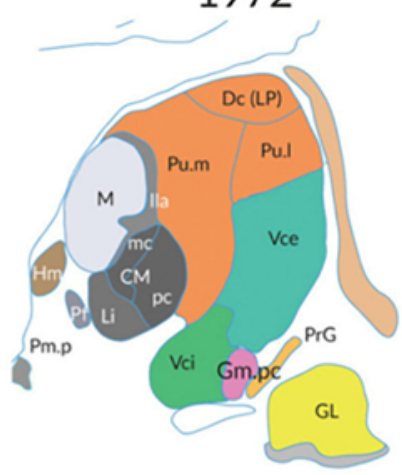

Percheron 2004

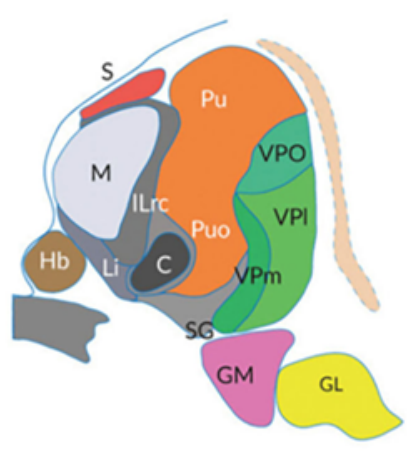

Mai et al. 2016

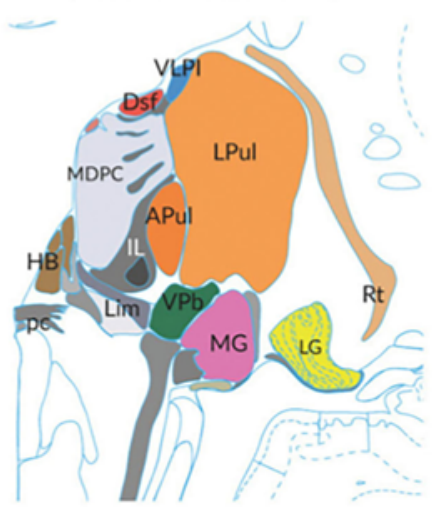

Hassler 1977

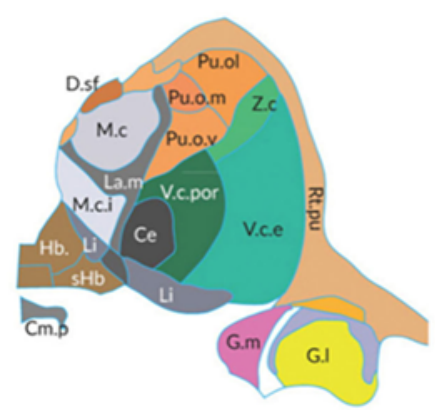

Morel 2007

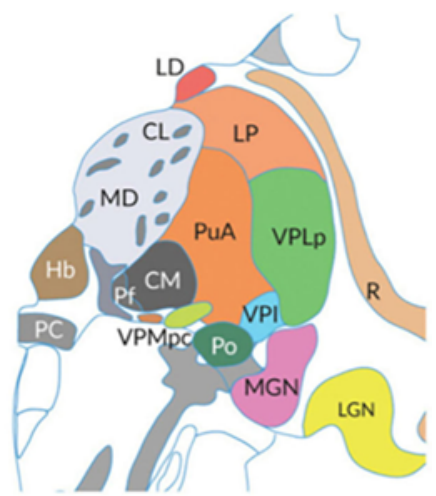

Mai / Majtanik 2017

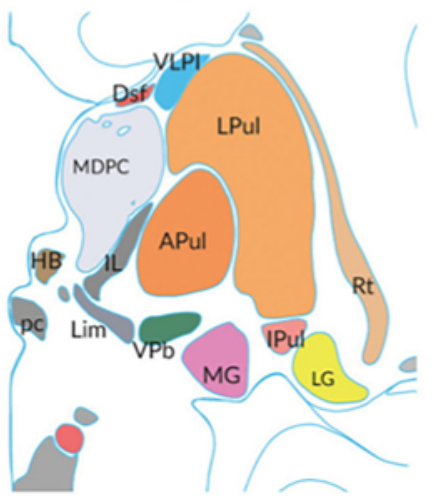

FIG. 6. Depictions of a coronal section of the thalamus at the level of the posterior commissure. The figure illustrates the discrepancies in nuclear borders and nomenclature reported by the different authors named in the figure. Reprinted from Mai J, Majtanik M: Toward a common terminology for the thalamus. Front Neuroanat 12:114, 2019 (C Jürgen K. Mai and Milan Majtanik), CC BY 4.0 (https://creativecommons.org/licenses/by/4.0/).

connections. Further insights into thalamic connections and function came in 1885, thanks to the introduction of Marchi's technique, ${ }^{34}$ a method based on the anterograde staining of degenerating myelinated fibers that allowed the identification of deep thalamic connections, such as the trigeminothalamic tract, ${ }^{64}$ the spinothalamic tract, ${ }^{19}$ the auditory pathway, ${ }^{9}$ the optic tract, ${ }^{38}$ cerebellothalamic afferences,${ }^{33}$ and the ansa peduncularis.$^{68,74}$ The reliability of the Marchi technique, however, was limited to myelinated fibers.

In 1954, Nauta and Gygax introduced a new staining technique, ${ }^{42}$ which allowed selective visualization of both myelinated and nonmyelinated axon terminals that were undergoing Wallerian degeneration. The main problem with Nauta's method, as well as those of his forerunners, was that it depended on pathological changes in the speci- 


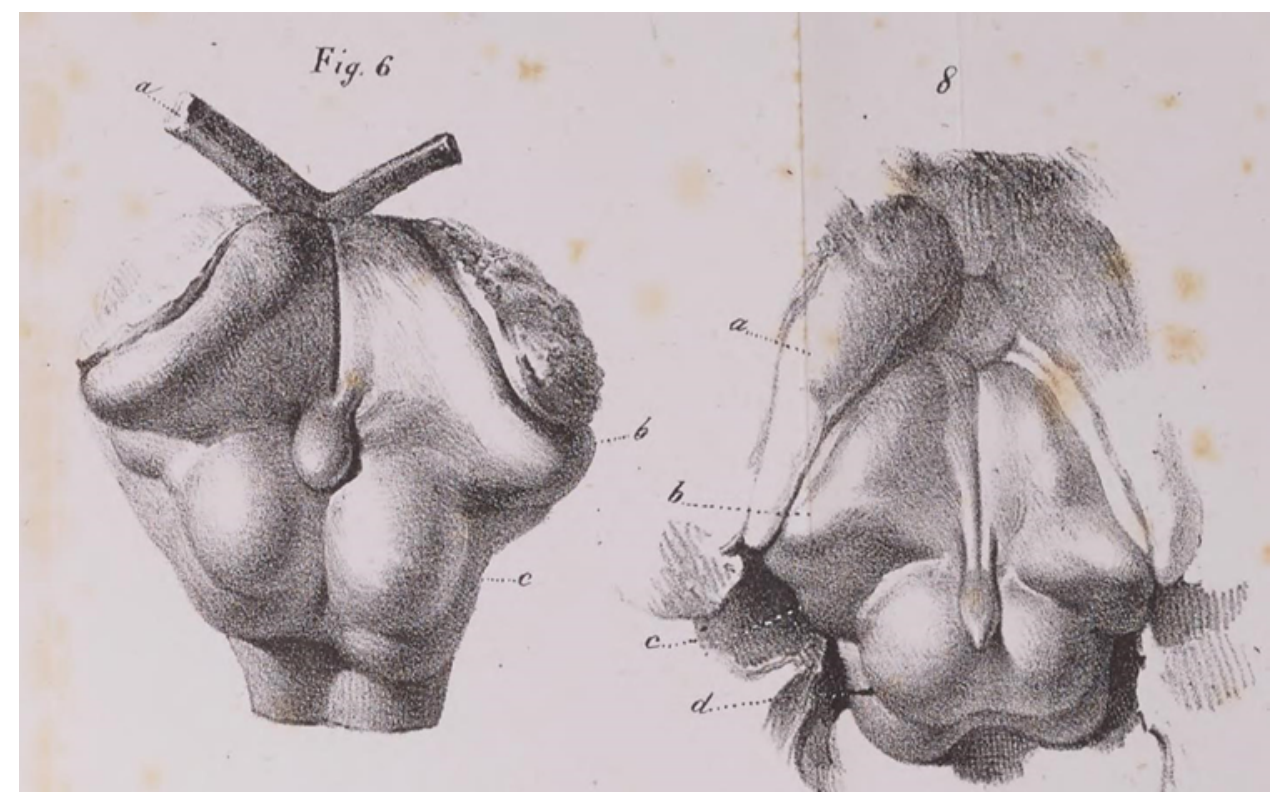

FIG. 7. Illustrations from Bartolomeo Panizza's "Osservationi sul nervo ottico." Left: Drawing of a specimen from the brain of a horse that had died years after having accidentally lost the right eye. There is evidence of right optic nerve and right thalamus hypertrophy with contralateral atrophy. Right: Drawing of a specimen from a 5-month-old calf brain that was blind in the left eye due to a neonatal lesion. Hypertrophy of the "olfactory" and "optic" left thalamus is seen with contralateral atrophy. From Bartolomeo Panizza, Osservazioni sul nervo ottico. In Memorie dell' I. R. Istituto lombardo di scienze, lettere ed arti: Istituto lombardoAccademia di scienze e lettere" (Milano, 1856, public domain).

mens-in order to observe degenerating fibers, a lesion had to be caused. But such lesions were not often precise for technical reasons, and, as a consequence, the observed pattern of degeneration was also aspecific. As a matter of fact, despite significant technical improvements, all lesional studies, either induced (in experimental animals) or observed (in humans), still suffered from a limited reproducibility. On top of this, there were limitations inherent to the staining technique.

These latter limitations were partly overcome with the development of the anterograde autoradiographic technique in $1983 .{ }^{17}$ This method is based on the physiological process of axoplasmic transportation of polypeptides derived from radioactive amino acids, which are taken up in the somata, transformed, and then transported to the axon's terminal, thus guaranteeing a high degree of specificity. Nonetheless, this innovative method was relatively quickly overtaken by retrograde tracing of horseradish peroxidase ${ }^{26}$ from axon terminals to neuron somata, mainly because of the more limited technical demands of the latter technique. More sensitive fluorescent tracers were then introduced in the late 1980s, in combination with the introduction of immunocytochemical methods. The obvious limitation of these techniques was that, having to rely on a physiological process, they could not be used in the human thalamus but only in that of experimental animals. ${ }^{57}$

\section{Electrophysiology of the Human Thalamus}

Studies of the electrophysiology of the thalamus started to appear in the first half of the 20th century and con- sisted of electroencephalographic recordings of thalamic activity $^{3}$ and the registration of thalamic responses to peripheral stimuli. ${ }^{35}$ These areas of investigation led to the involvement of the thalamus in the mechanisms of arousal and consciousness ${ }^{59}$ and to the identification of specific potentials in thalamo-cortical pathways. ${ }^{49} \mathrm{~A}$ significant boost was given to the study of thalamic physiology by the development of functional neurosurgery for movement disorders, which allowed investigators to register for the first time the effect of thalamic stimulation or lesions in vivo in the human being, thus overcoming the heavy limitation of previous studies in animals. The generalizability of data obtained from patients suffering from neurological disease remains limited, however. Moreover, only some portions of the thalamus can be studied with this method.

To summarize, the main problem concerning the understanding of thalamic function lies in the fact that most available data derive from studies on nonhuman primates or postmortem human specimens. In vivo anatomo-functional correlations regarding the thalamus remain particularly difficult in humans. Lesional or tracing studies cannot be done in humans, whereas "spontaneous" lesional studies (such as clinical studies of ischemic or hemorrhagic thalamic strokes) are often not selective enough. ${ }^{56}$ Moreover, in vivo correlations between the topography of a lesion and its clinical effect are only as accurate as the available neuroimaging can be. ${ }^{4}$ Despite considerable technical advances, ${ }^{2,27}$ neuroimaging is still far from accurately depicting the in vivo human microscopic anatomy of the thalamus. ${ }^{21}$ 


\section{Conclusions}

The development of the current knowledge about the function of the human thalamus is the result of a long process over several centuries, which proceeded inextricably intermingled with the increasing accumulation of data about thalamic macro- and microscopic anatomy and with the improvement of the technological tools available. The ex vivo thalamic anatomy on both the macro- and microscale can be considered well understood. Considerable effort has been recently put into unifying the terminology relative to the internal microscopic architecture and connectivity of the thalamus, a step essential to consistently ascertaining anatomo-functional correlations. The understanding of the function of the thalamus could benefit from ex vivo (postmortem) studies on human specimens and in vivo studies on nonhuman primates. An appreciation of the function of the human thalamus in vivo is still confronted with significant challenges and technical limitations.

\section{References}

1. Arnold F: Tabulae anatomicae: quas ad naturam accurate descriptas in lucem edidit. Zürich: Orellii, Fuesslini, 1838, Vol 1

2. Behrens TE, Johansen-Berg H, Woolrich MW, Smith SM, Wheeler-Kingshott CA, Boulby PA, et al: Non-invasive mapping of connections between human thalamus and cortex using diffusion imaging. Nat Neurosci 6:750-757, 2003

3. Berger H: Über das Elektrenkephalogramm des Menschen. Arch Psychiatr Nervenkr 87:527-570, 1929

4. Bogousslavsky J, Regli F, Uske A: Thalamic infarcts: clinical syndromes, etiology, and prognosis. Neurology 38:837-848, 1988

5. Burdach KF: Vom Baue und Leben des Gehirns. Leipzig: Dyk, 1822

6. Craig AD, Bushnell MC, Zhang ET, Blomqvist A: A thalamic nucleus specific for pain and temperature sensation. Nature 372:770-773, 1994

7. Déjerine J: Anatomie des centres nerveux par J. Dejerine Avec la collaboration de Madame Dejèrine-Klumpke. Paris: Rueff et Cie, 1895

8. Ferrier D: The Functions of the Brain. New York: G.P. Putnam's Sons, 1876

9. Ferrier D, Turner WA: III. A record of experiments illustrative of the symptomatology and degenerations following lesions of the cerebellum and its peduncles and related structures in monkeys. Proc R Soc Lond 54:476-478, 1894

10. Flourens P: Recherches expérimentales sur les propriétés et les fonctions du système nerveux dans les animaux vertébrés. Paris: Baillière, 1842

11. Forel A: Untersuchungen über die Haubenregion und ihre oberen Verknüpfungen im Gehirne des Menschen und einiger Säugethiere, mit Beiträgen zu den Methoden der Gehirnuntersuchung. Arch Psychiatr Nervenkr 7:393-495, 1877

12. Fournié E: Recherches expérimentales sur le fonctionnement du cerveau. Paris: Delahaye, 1873

13. Foville AL, Beau É, Bion F: Traité complet de l'anatomie, de la physiologie et de la pathologie du système nerveux cérébro-spinal. Paris: Fortin, Masson et cie, 1844

14. Friedemann M: Die Cytoarchitektonik des Zwischenhirns der Cercopitheken mit besonderer Berücksichtigung des Thalamus opticus. J Psychol Neurol 18:309-378, 1911

15. Fritsch G, Hitzig E: Ueber die elektrische Erregbarkeit des Grosshirns. Leipzig: Veit, 1870

16. Gailloud P, Carota A, Bogousslavsky J, Fasel J: Histoire de l'anatomie du thalamus de l'antiquité à la fin du XIXe siècle.. Schweiz Arch Neurologie Psych 154:49-58, 2003

17. Gerfen CR, Sawchenko PE: An anterograde neuroanatomical tracing method that shows the detailed morphology of neurons, their axons and terminals: immunohistochemical localization of an axonally transported plant lectin, Phaseolus vulgaris leucoagglutinin (PHA-L). Brain Res 290:219-238, 1984

18. Golgi C: Sulla fina struttura dei bulbi olfattori. Riv Sper Freniatria Med Legal 1:66-78, 1875

19. Gowers WR: On the antero-lateral ascending tract of the spinal cord. Lancet 1:1153-1154, 1886

20. Hirai T, Jones EG: A new parcellation of the human thalamus on the basis of histochemical staining. Brain Res Brain Res Rev 14:1-34, 1989

21. Iglesias JE, Insausti R, Lerma-Usabiaga $\mathrm{G}$, Bocchetta $\mathrm{M}$, Van Leemput K, Greve DN, et al: A probabilistic atlas of the human thalamic nuclei combining ex vivo MRI and histology. Neuroimage 183:314-326, 2018

22. Ilinsky IA, Kultas-Ilinsky K: Sagittal cytoarchitectonic maps of the Macaca mulatta thalamus with a revised nomenclature of the motor-related nuclei validated by observations on their connectivity. J Comp Neurol 262:331-364, 1987

23. Jakob C, Onelli CI: Vom Tierhirn zum Menschenhirn, I. Teil: Tafelwerk nebst Einführung in die Geschichte der Hirnrinde. Munich: JF Lehmann's Verlag, 1911

24. Jones EG: The Thalamus. Cambridge: Cambridge University Press, 2007

25. Klingler J: Ein zerlegbares Modell der Vorder-und Mittelhirnkerne des Menschen mit Einschluß der angrenzenden Rindenpartien. Z Anat Entwicklungsgesch 111:1-90, 1942

26. Kristensson K, Olsson Y, Sjöstrand J: Axonal uptake and retrograde transport of exogenous proteins in the hypoglossal nerve. Brain Res 32:399-406, 1971

27. Lemaire JJ, Sakka L, Ouchchane L, Caire F, Gabrillargues J, Bonny JM: Anatomy of the human thalamus based on spontaneous contrast and microscopic voxels in high-field magnetic resonance imaging. Neurosurgery 66 (3 Suppl Operative): $161-172,2010$

28. Luys J: Iconographie photographique des centres nerveux: ouvrage accompagné d'un atlas de soixante-dix photographies et de soixante-cinq schémas lithographiés. Paris: Baillière, 1873, Vol 1

29. Luys JB: Recherches sur le système nerveux cérébrospinal: sa structure, ses fonctions et ses maladies. Paris: Baillière, 1865

30. Macchi G, Jones EG: Toward an agreement on terminology of nuclear and subnuclear divisions of the motor thalamus. $\mathbf{J}$ Neurosurg 86:77-92, 1997

31. Magendie F: Leçons sur les fonctions et les maladies du système nerveux. Paris: Lecaplain, 1841

32. Mai JK, Majtanik M: Toward a common terminology for the thalamus. Front Neuroanat 12:114, 2019

33. Marchi V: Sull' origine e decorso dei peduncoli cerebellari e sui loro rapporti cogli altri centri nervosi. Florence: successori Le Monnier, 1891

34. Marchi V, Algeri G: Sulle degenerazioni discendenti consecutive a lesioni sperimentale in diverse zone della corteccia cerebrale. Riv Sper Freniatria Med Legal 11:492-494, 1885

35. Marshall WH: Observations on subcortical somatic sensory mechanisms of cats under nembutal anesthesia. J Neurophysiol 4:25-43, 1941

36. Mayo H: A Series of Engravings Intended to Illustrate the Structure of the Brain and Spinal Cord in Man. London: Burgess and Hill, 1827

37. Meynert T: Psychiatrie. Klinik der Erkrankungen des Vorderhirns begründet auf dessen Bau, Leistungen und Ernährung. Vienna: Wilhelm Braumüller, 1884 
38. Minkowski M: Experimentelle Untersuchungen über die Beziehungen der Grosshirnrinde und der Netzhaut zu den primären optischen Zentren, besonders zum Corpus geniculatum externum. Munich: J.F. Bergmann, 1913

39. Monro A: Observations on the structure and functions of the nervous system, illustrated with tables. London Med J 4:113-135, 1783

40. Morel A, Magnin M, Jeanmonod D: Multiarchitectonic and stereotactic atlas of the human thalamus. J Comp Neurol 387:588-630, 1997

41. Mundinus: Anatomia di Mundino, in Montagnano PD (ed): Fasciculo di medicina. Venezia: Giovanni et Gregorio de'Gregorii, 1493

42. Nauta WJ, Gygax PA: Silver impregnation of degenerating axons in the central nervous system: a modified technic. Stain Technol 29:91-93, 1954

43. Nissl F: Die Grosshirnanteile des Kaninchens. Arch Psychiatr Nervenkr 52:867-953, 1913

44. Nissl F: Die Kerne des Thalamus beim Kaninchen. Neurol Zentralbl 8:549-550, 1889

45. Nothnagel H: Experimentelle Untersuchungen über die Functionen des Gehirns. Arch Pathol Anat Physiol Klin Med 68:33-58, 1876

46. Olszewski J: The Thalamus of the Macaca mulatta. An Atlas for Use with the Stereotaxic Instrument. New York: Karger, 1952

47. Panizza B: Memorie dell' I. R. Istituto Lombardo di Scienze, Lettere ed Arti. Milan: Tipografia Bernardoni, 1856

48. Percheron G, François C, Talbi B, Yelnik J, Fénelon G: The primate motor thalamus. Brain Res Brain Res Rev 22:93181,1996

49. Purpura DP: Activation of "secondary" impulse trigger sites in hippocampal neurones. Nature 211:1317-1318, 1966

50. Riolan J: Antropographia et Osteologia. Paris: Moreau, 1626

51. Rolando L: Saggio sopra la vera struttura del cervello dell'uomo e degli animali e sopra le funzioni del sistema nervoso. Sassari: Nella Stamperia Da SSRM Privilegiata, 1809

52. Roussy G: La couche optique (étude anatomique, physiologique \& clinique). Le syndrome thalamique. Paris: G. Steinheil, 1907

53. Santorini GD, Girardi M: Anatomici summi septemdecim tabulae quas nunc primum edit atque explicat iisque alias addit de structura mammarum et de tunica testis vaginalis. Parma: Ex Regia Typographia, 1775

54. Schaltenbrand G, Wahren W, Hassler RG: Atlas for Stereotaxy of the Human Brain. Stuttgart: Thieme, 1977

55. Schlesinger B, Ferner H: The Upper Brainstem in the Human: Its Nuclear Configuration and Vascular Supply. Berlin: Springer, 1976

56. Schmahmann JD: Vascular syndromes of the thalamus. Stroke 34:2264-2278, 2003

57. Schmahmann JD, Pandya DN: Fiber Pathways of the Brain. New York: Oxford University Press, 2009

58. Serra C, Türe U, Krayenbühl N, Şengül G, Yaşargil DC, Yaşargil MG: Topographic classification of the thalamus surfaces related to microneurosurgery: a white matter fiber microdissection study. World Neurosurg 97:438-452, 2017

59. Steriade MM, McCarley RW: Brainstem Control of Wakefulness and Sleep. New York: Springer US, 1990
60. Stricker S, Arnold J: Handbuch der Lehre von den Geweben des Menschen und der Thiere. Leipzig: W. Engelmann, 1871, Vol 1

61. Stricker S, Arnold J: Handbuch der Lehre von den Geweben des Menschen und der Thiere. Leipzig: W. Engelmann, 1872, Vol 2

62. Sudhoff K: Ein Beitrag zur Geschichte der Anatomie im Mittelalter: speziell der anatomischen Graphik nach Handschriften des 9. bis 15. Jahrhunderts. Leipzig: Barth, 1908

63. Ten Donkelaar HJ, Broman J, Neumann PE, Puelles L, Riva A, Tubbs RS, et al: Towards a Terminologia Neuroanatomica. Clin Anat 30:145-155, 2017

64. van Gehuchten A: Recherches sur les voies sensitives centrales: la voie centrale du trijumeau. Nevraxe 3:235-261, 1901

65. von Gudden B: Experimentaluntersuchungen über das peripherische und centrale Nervensystem. Arch Psychiatr Nervenkr 2:693-723, 1870

66. von Monakow C: Experimentelle und pathologisch-anatomische Untersuchungen über die Haubenregion, den Sehhügel und die Regio subthalamica, nebst Beiträgen zur Kenntniss früh erworbener Gross- und Kleinhirn-defecte. Arch Psychiatr Nervenkr 27:1-128, 1895

67. von Monakow C: Experimentelle und pathologisch-anatomische Untersuchungen über die optischen Centren und Bahnen. Arch Psychiatr Nervenkr 20:714-787, 1889

68. Vogt C, Vogt O: Zur Lehre der Erkrankungen des striären Systems. J Psychol Neurol 25:627-846, 1920

69. Vogt O, Vogt C: Thalamusstudien I-III. J Psychol Neurol 50:31-154, 1941

70. Vulpian A, Brémond E: Leçons sur la physiologie générale et comparée du systéme nerveux: faites au Muséum d'Histoire Naturelle. Paris: Baillière, 1866

71. Walker AE: The Primate Thalamus. Oxford, England: University of Chicago Press, 1938

72. Weigert C: Über eine neue Untersuchungsmethode des Centralnervensystem. Z Med Wiss 20:753-757, 772-774, 1882

73. Willis T: Cerebri Anatome. London: Flesher, Martyn \& Allestry, 1664

74. Wilson SAK: An experimental research into the anatomy and physiology of the corpus striatum. Brain 36:427-492, 1914

\section{Disclosures}

The authors report no conflict of interest concerning the materials or methods used in this study or the findings specified in this paper.

\section{Author Contributions}

Conception and design: Serra. Acquisition of data: Serra, Guida, Staartjes, Türe. Analysis and interpretation of data: Serra, Guida. Drafting the article: Serra, Guida, Türe. Critically revising the article: Serra, Krayenbühl, Türe. Reviewed submitted version of manuscript: Serra, Türe. Approved the final version of the manuscript on behalf of all authors: Serra. Study supervision: Serra.

\section{Correspondence}

Carlo Serra: Clinical Neuroscience Centre, University Hospital Zürich, University of Zürich, Switzerland. c.serra@hotmail.it. 